\title{
Studi karakteristik sub kronis limbah bahan berbahaya dan beracun fly ash industri pulp dan kertas PT. Riau Andalan Pulp and Paper
}

\author{
Jailani ${ }^{1}$, Aras Mulyadi ${ }^{2}$, Rahmat Karnila ${ }^{2}$ \\ ${ }^{1}$ PT. Riau Andalan Pulp and Paper \\ ${ }^{2}$ Dosen Pascasarjana Ilmu Lingkungan Program Pascasarjana Universitas Riau. \\ *Correspondent email : djailaniaron@yahoo.co.id
}

\begin{abstract}
Sub chronic Characteristics Study of Hazardous waste fly ash Pulp and Paper Industry PT Riau Andalan Pulp and Paper aimed to observed hazardous waste characteristics, both physical or toxically characteristics (TCLP, LD50, and Sub chronic), to observe the influence of fly ash doses to mice trough toxic sub chronic characteristics tes. The research methods used survey and experimental method. Survey method is used to analyze certificate of analysis data from fly ash characteristic tesed .Experimental method is used for sub chronic tes to mice animals tes in 90 days with dosage, control $(0$ $\mathrm{mg} / \mathrm{kg}$ body weight ), low (5 $\mathrm{mg} / \mathrm{kg}$ body weight), medium (50 $\mathrm{mg} / \mathrm{kg}$ body weigh), and high (500 $\mathrm{mg} / \mathrm{kg}$ body weight). Results of this research showed that fly ash from Pulp and Paper Industry PT $R A P P$ passed characteristics tes of explosive, flammable, reactive and toxic characteristics $\left(T C L P, L D_{50}\right.$, and Sub chronic). Dosage of fly ash level in $0 \mathrm{mg} / \mathrm{kg}$ body weight, $5 \mathrm{mg} / \mathrm{kg}$ body weight, $50 \mathrm{mg} / \mathrm{kg}$ body weight, $500 \mathrm{mg} / \mathrm{kg}$ body weight for 90 days are not influences for increasing the weight of mice body, food and beverage intake, metabolism of carbohydrates, proteins and fats, hematology and NOAEL value is over $500 \mathrm{mg} / \mathrm{kg}$ weight of body. Based on this research had been concluded that fly ash from Pulp and Paper Industry PT RAPP not identified as hazardous waste and can be submitted to KLHK for do exceptions study as hazardous waste in accordance with article 191 PP 101 Year 2014.
\end{abstract}

Keywords: riau; pt rapp; limbah fly ash; sub chronic

PT. Riau Andalan Pulp dan Paper (PT RAPP) merupakan salah satu industri pulp dan kertas yang berkedudukan di Pangkalan Kerinci Riau. PT RAPP dalam pemenuhan energi untuk menunjang produksi menggunakan kulit kayu dan black liquor (sisa cairan pemasak pulp) sebagai bahan bakar utama. Kulit kayu digunakan sebagai bahan bakar di power boiler dan black liqour sebagai bahan bakar di recovery boiler. Bahan bakar batubara dan sludge Instalasi Pengolahan Air Limbah (IPAL) digunakan sebagai bahan bakar tambahan di power boiler. Pembakaran kulit kayu, batubara dan sludge IPAL di power boiler menghasilkan limbah padat berupa fly ash dan bottom ash, sedangkan pembakaran black liqour akan menghasilkan limbah padat berupa dregs. Menurut Purwati, et al., (2007) limbah fly ash PT.RAPP pengelolaannya dengan metode penimbunan akhir di landfill. Pengelolaan fly ash tersebut merupakan pengelolaan yang tidak ramah lingkungan dan tidak memberi manfaat kepada masyarakat.

Fly ash adalah abu dari hasil pembakaran pada tungku pembakaran (boiler) berbentuk partikel halus, warna agak keabu-abuan, memiliki kadar karbon yang rendah dan bersifat penzolanik. Menurut Peraturan Pemerintah (PP) No. 101 Tahun 2014, fly ash industri pulp dan kertas dikategorikan limbah bahan berbahaya dan beracun (limbah B3) karena adanya pembakaran batubara dan sludge dari IPAL yang diduga mengandung logam berat yang tinggi dan terjadi proses pelindian pada saat penggunaan. Sedangkan menurut U.S. Environmental Protection Agency, (2015), mengklasifikasikan fly ash dari pembakaran batubara sebagai limbah "non-hazardous waste" dan special waste

Berdasarkan Peraturan Pemerintah No. 101 Tahun 2014 tentang pengelolaan limbah bahan berbahaya dan beracun (limbah B3), limbah fly ash dikategorikan limbah B3 dari sumber spesifik khusus. Limbah B3 tersebut dapat dikeluarkan dari tabel limbah B3 jika telah melaksanakan dan lolos uji; 1). Karakteristik mudah meledak, mudah menyala, reaktif, infeksius dan atau korosif sesuai dengan parameter uji sebagaimana tercantum dalam Lampiran 2 peraturan pemerintah tersebut; 2). Karakteristik beracun melalui uji toksikologi Lethal Dosage $\left(\mathrm{LD}_{50}\right)$; 3). Karakteristik beracun melalui Toxicity Concentration Leaching Prosedure (TCLP) dan 4). Karakteristik beracun melalui uji toksikologi sub kronis sesuai dengan parameter uji. Mengingat permasalah di atas, penelitian ini sangat diperlukan untuk mengkaji karakteristik fly ash yang dipersyaratkan memenuhi baku mutu dan persyaratan untuk pengajuan proses pengecualian di atas sehingga pengelolaan fly ash ke depan lebih ramah lingkungan dengan memaksimalkan pemanfaatan. Penelitian ini bertujuan untuk mengetahui karakteristik fly ash, pengaruh pemberian dosis fly ash PT.RAPP terhadap efek toksik, berat badan, asupan makanan atau minuman dan hematologi mencit pada uji sub kronis selama 90 hari. 


\section{METODE PENELITIAN}

Penelitian ini dilaksanakan pada Maret 2015 sampai September 2015 di PT. Riau Andalan Pulp and Paper (PT. RAPP) Pangkalan Kerinci dan Lembaga Pengujian dan Penelitian Terpadu (LPPT) Universitas Gajah Mada (UGM) Yogyakarta. Metode penelitian yang digunakan adalah metode survei dan eksperimen. Survei dilakukan untuk pengumpulan data hasil pengujian yang telah dilakukan oleh PT RAPP terhadap karakteristik fly ash yang berupa certifate analysis dan metode eksprimen dilakukan untuk uji karakteristik sub kronis terhadap fly ash di PT. RAPP. Analisis dilakukan untuk mengamati karakteristik fisik, karakteristik beracun $\mathrm{LD}_{50}$ dan karakteristik beracun TCLP.

\section{Uji karakteristik fisik}

Uji karakteristik ini meliputi mudah meledak, mudah menyala (US EPA SW-846-1010), korosif (US EPA SW-846-9045) dan reaktifitas (US EPA SW-846-9010), yang amati adalah karakteristik mudah meledak pada suhu dan tekanan standar yaitu $25^{\circ} \mathrm{C}$ atau $760 \mathrm{mmHg}$, mudah menyala dengan mengukur titik nyala tidak kurang dari $60^{\circ} \mathrm{C}$, reaktif dengan mengamati reaksi dengan air menghasilkan gas atau ledakan, bukan senyawa yang mengandung Sianda dan $\mathrm{H}_{2} \mathrm{~S}$ yang menghasilkan gas pada $\mathrm{pH} 2-12,5$ dan reaktifitas dengan terbentuk atau perubahan warna serta uji korosif dengan mengukur $\mathrm{pH}$. Hasil pengamatan yang didapat berupa data kualitatif (positif atau negatif) dan dianalisis secara deskriptif terhadap baku mutu PP No. 101 Tahun 2014.

\section{Uji karakteristik beracun LD50}

Hasil uji yang telah dilakukan oleh PT.RAPP tahun 2012 di Laboratorium PT. ALS mengacu pada 96 hours acute oral toxicity (US EPA 1998 and OECD 2001) terhadap 30 ekor mencit betina dan 30 mencit jantan dengan berat badan (BB) rata-rata 21,9 gr dan tingkat dosis $0 \mathrm{mg} / \mathrm{kg} \mathrm{BB}, 1.242 \mathrm{mg} / \mathrm{kg} \mathrm{BB}, 2.305$ $\mathrm{mg} / \mathrm{kg} \mathrm{BB}, 4.234 \mathrm{mg} / \mathrm{kg} \mathrm{BB}, 8.995 \mathrm{mg} / \mathrm{kg} \mathrm{BB}$ dan $18.778 \mathrm{~kg} \mathrm{BB}$. Pengamatan dilakukan terhadap tingkat kematian (persen mortalitas) oleh pemberian dosis tersebut dan gross necropcy diakhir pengujian. Hasil ini kemudian dianalis secara deskriptif terhadap baku mutu PP No. 101 Tahun 2014.

\section{Uji Karakteristik beracun TLCP}

Uji yang telah dilakukan oleh PT.RAPP Tahun 2014 di Laboratorium PT.ALS mengacu pada metode analisa APHA3125-B dengan parameter logam berat seperti $\mathrm{Sb}, \mathrm{As}, \mathrm{Ba}, \mathrm{Be}, \mathrm{B}, \mathrm{Cd}, \mathrm{Cr}, \mathrm{Cu}, \mathrm{Pb}, \mathrm{Hg}$, $\mathrm{Mo}, \mathrm{Ni}, \mathrm{Se}, \mathrm{Ag}$ dan Sn. Hasil analisa tersebut dideskripsikan dan dibandingkan dengan baku mutu dan peraturan yang berlaku (PP No. 101 Tahun 2014)

\section{Uji Karakteristik beracun Sub kronis}

Uji ini merupakan uji eksperimen yang di laboratorium LPPT UGM dengan mengacu pada Metode Repeated Dose 90-day oral toxicity study in rodents (Organization for Economic and Community Development guideline 408). Uji ini dilakukan dengan pemberian beberapa dosis fly ash terhadap mencit jantan dan betina selama 90 hari. Rancangan percobaan yang digunakan rancangan acak lengkap (RAL) pola satu arah dengan tingkat dosis fly ash secara oral, kontrol $(0 \mathrm{mg} / \mathrm{kg} \mathrm{BB})$, rendah $(5 \mathrm{mg} / \mathrm{kg} \mathrm{BB})$, tengah $(50 \mathrm{mg} / \mathrm{kg}$ $\mathrm{BB}$ ), dan tinggi (500 mg/kg BB) terhadap 10 ekor mencit jantan dan 10 ekor mencit betina. Jumlah mencit yang diberikan dosis fly ash menjadi ulangan setiap parameter. Selama percobaan, mencit diberikan makanan berupa pellet, minuman dan dosis fly ash dengan larutan pembawa Natrium Carboxil Cellulosa 0,5 $\%$ selama 90 hari. Pengamatan yang dilakukan selama percobaan adalah gejala-gejala efek toksik yang meliputi sistem susunan saraf pusat dan somatomotor, saraf otonom, pernafasan, kardiovaskular, saluran cerna, genitourinari, membran mukosa dan mata, asupan makanan dan minuman, dan berat badan mencit.

Pengamatan hematologi dilakukan setelah percobaan selesai dan mencit diambil darahnya untuk dianalisa yang meliputi jumlah sel darah puth (WBC), sel darah merah (RBC), hemoglobin ( $\mathrm{Hb}$ ), hematocrit (HCT), platelet (PLT), limfosit (Lymp), MCHC (Mean Corpuscular Hemoglobin Concentration) dan MCV (Mean Cospucular Volume), kimia darah meliputi glukosa, protein total, albumin, kolesterol, ALT (Alanine Aminotransferase), AST (Aspartan Aminotransferase), bilirubin total, dan kreatinin serum .

Selanjutnya untuk mengamati sifat reversibilitas toksik dilakukan percobaan terhadap kelompok satelit pada tingkat dosis fly ash kontrol ( $0 \mathrm{mg} / \mathrm{kg}$ berat badan) dan dosis tertinggi ( $500 \mathrm{mg} / \mathrm{kg}$ berat badan) terhadap 5 ekor mencit jantan dan 5 ekor mencit betina. Pemberian dosis pada kelompok ini dilakukan selama 90 hari dan dilanjutkan pemulihan (pemberhentian dosis) selama 28 hari (118 hari pengamatan).

Data-data hasil pengamatan tersebut dievaluasi dan dianalisis secara deskriptif dan statistik. Data penimbangan berat badan diamati setiap hari, dirata-ratakan perminggu dan dihitung purata kenaikan berat perhari (PKBP) atau Average Daily Gain. Selanjutnya PKBP antar kelompok dianalisis secara statistik 
dengan ANNOVA satu jalan non faktorial dan diuji lanjut dengan Duncan New Multiple Range Tes. Data jumlah asupan makanan dan minuman perhari dihitung perbedaan purata mingguan antar kelompok perlakuan, selanjutnya dianalisis secara deskriptif. Gejala-gejala klinis (efek toksik) yang teramati dianalisis secara kualitatif/deskriptif. Hasil pemeriksaan hematologi dirata-ratakan perkelompok dosis dan hasil hematologi di analisis secara deskriptif terhadap referensi dan untuk melihat pengaruh pemberian dosis $f l y$ ash terhadap kontrol dianalisis secara statistik dengan ANNOVA satu jalan non faktorial dan dilanjutkan dengan uji lanjut Duncan New Multiple Range Test.

\section{HASIL DAN PEMBAHASAN}

\section{Karakteristik Fisik Fly Ash}

Karakteristik fisik dari fly ash terdiri dari mudah meledak, mudah terbakar, reaktif dan korosif. Karakteristik fisik pada penelitian ini merupakan hasil analisis yang telah dilakukan oleh PT RAPP di Laboratorium PT ALS pada tahun 2012 yang tertuang dalam bentuk cerficate of analysis. Hasil analisis tersebut dapat dilihat pada Tabel 1.

Tabel 1. Hasil Uji Karakteristik Fly ash PT RAPP

Sumber: PT. RAPP 2012

Tabel di atas menunjukkan bahwa tes karakteristik mudah meledak (explosive) dan mudah terbakar

\begin{tabular}{|c|c|c|c|}
\hline No. & Parameter & Unit Satuan & Nilai \\
\hline \multicolumn{4}{|c|}{ Tes Karakterisrik } \\
\hline & Mudah Meledak & - & Tidak \\
\hline & Mudah Menyala & - & Tidak \\
\hline \multicolumn{4}{|c|}{ Reaktifitas } \\
\hline & Reaksi Dengan Air & - & Negatif \\
\hline & Tes H2S & - & Negatif \\
\hline & Tes $\mathrm{CN}^{-}$ & - & Negatif \\
\hline & Fisika dan Pembentukan Warna & - & Negatif \\
\hline & $\operatorname{Korosif}(\mathrm{pH} \leq 2,5$ atau $\mathrm{pH} \geq 12,5$ & - & 10,23 (tidak korosif) \\
\hline
\end{tabular}

(flammable) tidak explosive dan flammable (negatif), tes reaktifitas dengan air, $\mathrm{H}_{2} \mathrm{~S}$, Sianida dan pembentukan warna tidak reaktif (negatif). Tes $\mathrm{pH}$ untuk menentukan korosif hasilnya 10, 23 (tidak korosif) dimana suatu bahan dikatakan korosif jika $\mathrm{pH} \leq 2,5$ atau $\mathrm{pH} \geq 12,5$. Menurut hasil di atas, uji karakteristik fisik fly ash PT RAPP memenuhi baku mutu tidak (mudah meledak, mudah terbakar, reaktif dan korosif) yang dipersyaratkan PP No. 101 Tahun 2014. Hasil analisis tersebut menunjukkan bahwa fly ash PT RAPP tidak terindikasi limbah B3, hal ini sesuai dengan pengkategorian oleh US EPA, namun untuk memenuhi syarat limbah B3 tersebut dapat dikecualikan sebagai limbah B3 sesuai PP No. 101 Tahun 2014 perlu dilanjutkan uji karakteristik beracun.

\section{Karakteristik Beracun $\mathbf{L D}_{50}$}

Hasil uji karakteristik beracun $\mathrm{LD}_{50}$ fly ash yang telah dilakukan oleh PT. RAPP tahun 2012, di Laboratorium PT. ALS dapat dilihat pada (Tabel 2).

Tabel 2. Hasil Uji LD50 Fly ash PT RAPP

\begin{tabular}{cccccc}
\hline No. & Dosis mg/kg BB & Jumlah Hewan & Kematian & Hidup & \% Mortality \\
\hline 1 & 0 (kontrol) & 10 & 0 & 10 & 0,0 \\
2 & 1.242 & 10 & 0 & 10 & 0,0 \\
3 & 2.305 & 10 & 0 & 10 & 0,0 \\
4 & 4.234 & 10 & 0 & 10 & 0,0 \\
5 & 8.998 & 10 & 0 & 10 & 0,0 \\
6 & 18.779 & 10 & 0 & 10 & 0,0 \\
\hline
\end{tabular}

Sumber: PT. RAPP 2012. 
Hasil uji $\mathrm{LD}_{50}$ terhadap 10 ekor mencit Tabel 2 menunjukkan pemberian dosis 0 sampai 18,779 $\mathrm{mg} / \mathrm{kg}$ berat badan tidak ditemukan kematian selama seminggu percobaan dan hasil pengamatan gross necropsy tidak ditemukan kerusakan dan perbedaan limpa, ginjal, jantung, hati dan perut dibandingkan kontrol. Sehingga hasil $\mathrm{LD}_{50}$ di atas adalah 18,776 mg/kg BB. Bedasarkan PP No.74 Tahun 2001 bahwa hasil $\mathrm{LD}_{50}$ tersebut fly ash merupakan bahan yang relatif tidak berbahaya $(>15,000 \mathrm{mg} / \mathrm{kg} \mathrm{BB})$. Menurut PP No. 101 Tahun 2014 bahwa hasil uji $\mathrm{LD}_{50}$ tersebut tidak terindikasi limbah B3 karena limbah diidentifikasi sebagai limbah B3 dan dikatagorikan limbah B3 jika memiliki nilai $\mathrm{LD}_{50}$ oral 7 hari lebih besar atau sama dengan $50 \mathrm{mg} / \mathrm{kg}$ BB dan lebih kecil atau sama dengan $5000 \mathrm{mg} / \mathrm{kg}$ BB hewan uji mencit.

\section{Karakteristik Beracun Toxicity Concentration Leaching Prosedure (TCLP)}

Karakteristik beracun TCLP fly ash PT. RAPP diamati berdasarkan hasil analisis yang telah dilakukan terhadap fly ash PT. RAPP di laboratorium PT ALS tahun 2014 yang meliputi TCLP logam berat, inorganik, organik dan pestisida. Hasil analisis TCLP logam berat dapat dilihat pada Tabel 3.

Masuknya limbah ke dalam perairan akan mempengaruhi sifat-sifat biologis dari perairan tersebut (Marwan dalam Silitonga, 2014). Lalu lintas kapal penumpang, barang dan kapal nelayan potensial membuang limbah ke perairan melalui air buangan yang mengandung oli kotor dan ceceran minyak dari mesin kapal. Adanya aktivitas di atas kapal juga menghasilkan sampah seperti sisa makanan dan juga sampah-sampah material barang angkutan maupun sisa umpan nelayan.

Tabel 3. Hasil Analisa TCLP logam Berat dari Fly ash

\begin{tabular}{lccc}
\hline \multicolumn{1}{c}{ Parameter } & Satuan & Hasil & $\begin{array}{c}\text { Baku Mutu TCLP -B } \\
\text { PP No. 101 Tahun 2014 }\end{array}$ \\
\hline TCLP Metals & & & \\
Antimony (Sb) & $\mathrm{mg} / \mathrm{L}$ & $<0.05$ & 1,00 \\
Arsenic (As) & $\mathrm{mg} / \mathrm{L}$ & $<0.005$ & 0,50 \\
Barium (ba) & $\mathrm{mg} / \mathrm{L}$ & 0,21 & 35 \\
Berilium (be) & $\mathrm{mg} / \mathrm{L}$ & $<0.02$ & 0,5 \\
Boron (B) & $\mathrm{mg} / \mathrm{L}$ & 5,20 & 25 \\
Cadmium (Cd) & $\mathrm{mg} / \mathrm{L}$ & $<0.02$ & 0,15 \\
Chromium VI $\left(\mathrm{Cr}^{6+}\right)$ & $\mathrm{mg} / \mathrm{L}$ & $<0.02$ & 2,50 \\
Copper (Cu) & $\mathrm{mg} / \mathrm{L}$ & $<0.01$ & 10,00 \\
Lead (Pb) & $\mathrm{mg} / \mathrm{L}$ & $<0.05$ & 0,50 \\
Mercury (Hg) & $\mathrm{mg} / \mathrm{L}$ & $<0.0005$ & 0,05 \\
Molybdenum (Mo) & $\mathrm{mg} / \mathrm{L}$ & $<0.05$ & 3,50 \\
Nickel (Ni) & $\mathrm{mg} / \mathrm{L}$ & 0,04 & 3,50 \\
Selenium (Se) & $\mathrm{mg} / \mathrm{L}$ & $<0.0005$ & 0,50 \\
Silver(Ag) & $\mathrm{mg} / \mathrm{L}$ & $<0.02$ & 5,00 \\
Zinc (Zn) & $\mathrm{mg} / \mathrm{L}$ & 0,34 & 50,00 \\
\hline Sumber: PT. RAPP 2014 & & &
\end{tabular}

Tabel 3 menunjukkan kadar TCLP logam berat dari fly ash PT. RAPP, dimana semua parameter yang diuji mempunyai nilai di bawah nilai baku mutu. Parameter Merkuri dan Selenium mempunyai nilai yang paling rendah $<0,005 \mathrm{mg} / \mathrm{L}$ dan nilai yang tertinggi adalah Boron $(5,2 \mathrm{mg} / \mathrm{L})$ dan semua parameter logam berat yang bersifat toksik masih di bawah nilai baku mutu. Sehingga hasil uji TCLP logam berat fly ash PT. RAPP tidak terindikasi limbah B3 menurut baku mutu lampiran 3 PP No. 101 Tahun 2014. Menurut peraturan pemerintah (PP No. 101 Tahun 2014) Fly ash yang mengandung abu batubara dikategorikan limbah B3 karena diduga fly ash tersebut mengandung logam berat yang tinggi sehingga dapat terjadi pelindian ketika digunakan. Namun hasil analisis menunjukkan bahwa semua parameter yang di uji jauh dibawah baku mutu, hal ini disebabkan bahwa fly ash PT. RAPP merupakan fly ash dari pembakaran kulit kayu dan batubara, dan sesuai dengan hasil penelitian yang dilakukan oleh Purwati, et al. (2007) bahwa fly ash industri pulp dan kertas tidak terindikasi limbah B3 dan dapat digunakan sebagai ameliorant.

\section{Karakteristik Beracun Sub Kronis}

Sesuai dengan metode dan tujuan karakteristik sub kronis dilakukan untuk mengamati pengaruh pemberian dosis berulang fly ash secara oral terhadap hewan uji mencit selama 90 hari perlakuan (kelompok dosis) dan 118 hari (kelompok satelit).

\section{Pengaruh pemberian dosis $f l y$ ash terhadap gejala-gejala toksik}

Hasil pengamatan gejela-gejala fisik (toksik) hewan mencit jantan dan betina selama 90 hari pemberian berulang dosis fly ash terhadap sistem susunan saraf pusat dan somatomotor, saraf otonom, 
pernafasan, kardiovaskular, saluran cerna, genitourinari, membran mukosa dan mata yang diamati setiap hari dikumpulkan setiap minggunya dalam bentuk narasi pengamatan tidak ada (TA) jika tidak ditemukan adanya gejala toksik dan (A) jika temukan salah satu gejala toksik dapat dilihat pada Tabel 4.

Tabel 4. Hasil pengamatan gejala toksik mencit jantan dan betina selama pemberian dosis fly ash 90 hari

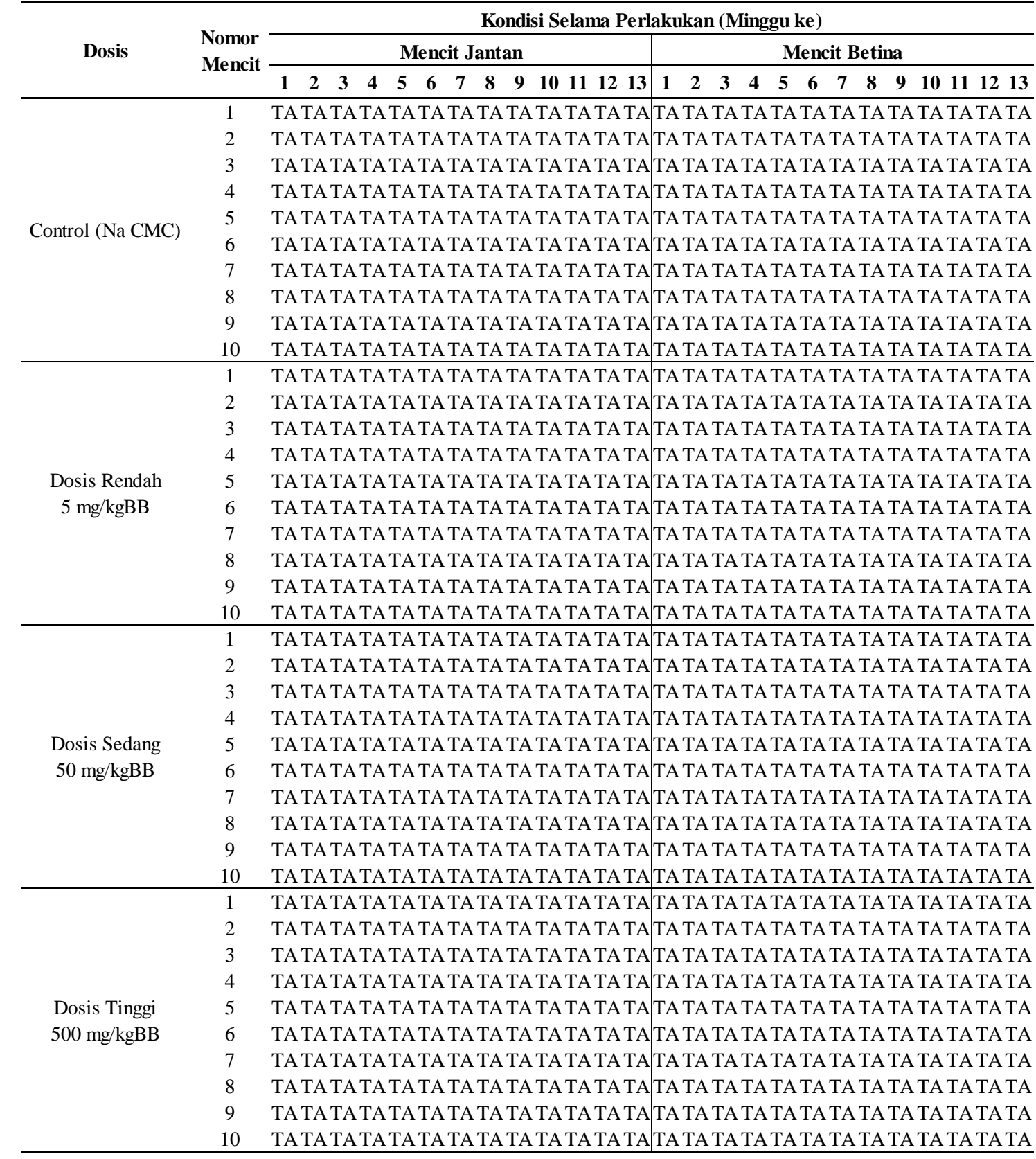

Keterangan (TA) : Tidak menunjukkan gejala toksit

Hasil pengamatan yang tertera di Tabel 4 menunjukkan bahwa pemberian dosis fly ash tidak ditemukan kelainan atau adanya gejala efek toksik baik untuk mencit jantan maupun mencit betina selama 90 hari pengamatan. Hal ini disebabkan kandungan racun dan logam berat dari fly ash sangat rendah (Anonimus 2006 dan Purwati et al, 2007). Sedangkan hasil pengamatan gejala toksik kelompok satelit (Tabel 5).

Tabel 5. Hasil pengamatan gejala toksik mencit jantan dan betina kelompok satelit

\begin{tabular}{ccccccccccccccccccc}
\hline \multirow{2}{*}{ Kelopok Satelit } & Nomor & \multicolumn{11}{c}{ Kondisi Selama Perlakukan (Minggu ke) } \\
& Mencit & $\mathbf{1}$ & $\mathbf{2}$ & $\mathbf{3}$ & $\mathbf{4}$ & $\mathbf{5}$ & $\mathbf{6}$ & $\mathbf{7}$ & $\mathbf{8}$ & $\mathbf{9}$ & $\mathbf{1 0}$ & $\mathbf{1 1}$ & $\mathbf{1 2}$ & $\mathbf{1 3}$ & $\mathbf{1 4}$ & $\mathbf{1 5}$ & $\mathbf{1 6}$ & $\mathbf{1 7}$ \\
\hline \multirow{3}{*}{ Kelompak Jantan } & 1 & TA & TA & TA & TA & TA & TA & TA & TA & TA & TA & TA & TA & TA & TA & TA & TA & TA \\
Dosis tingg & 2 & TA & TA & TA & TA & TA & TA & TA & TA & TA & TA & TA & TA & TA & TA & TA & TA & TA \\
500 mg/kgBB & 3 & TA & TA & TA & TA & TA & TA & TA & TA & TA & TA & TA & TA & TA & TA & TA & TA & TA \\
& 4 & TA & TA & TA & TA & TA & TA & TA & TA & TA & TA & TA & TA & TA & TA & TA & TA & TA \\
& 5 & TA & TA & TA & TA & TA & TA & TA & TA & TA & TA & TA & TA & TA & TA & TA & TA & TA \\
\hline \multirow{2}{*}{ Kelompok Betina } & 1 & TA & TA & TA & TA & TA & TA & TA & TA & TA & TA & TA & TA & TA & TA & TA & TA & TA \\
Dosis Tinggi & 2 & TA & TA & TA & TA & TA & TA & TA & TA & TA & TA & TA & TA & TA & TA & TA & TA & TA \\
500 mg/kgBB & 3 & TA & TA & TA & TA & TA & TA & TA & TA & TA & TA & TA & TA & TA & TA & TA & TA & TA \\
& 4 & TA & TA & TA & TA & TA & TA & TA & TA & TA & TA & TA & TA & TA & TA & TA & TA & TA \\
& 5 & TA & TA & TA & TA & TA & TA & TA & TA & TA & TA & TA & TA & TA & TA & TA & TA & TA \\
\hline
\end{tabular}


Hasil pengamatan Tabel 5 juga menunjukkan bahwa selama pemberian dosis fly ash 90 hari dan dilanjutkan pemberentian 28 hari tidak ditemukan adanya gejala toksik terhadap 5 ekor mencit jantan dan betina. Hal ini menunjukkan bahwa tidak adanya kelainan pada mencit baik secara sementara maupun permanen.

\section{Pengaruh pemberian dosis $f l y$ ash terhadap perkembangan bobot badan mencit}

Hasil pengamatan berat badan mencit setiap hari dicatat dan dirata-ratakan perminggu untuk kelompok dosis dapat dilihat pada (Gambar 1).

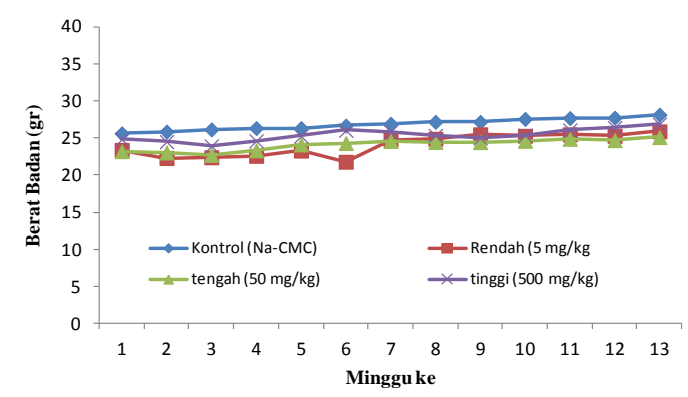

(a)

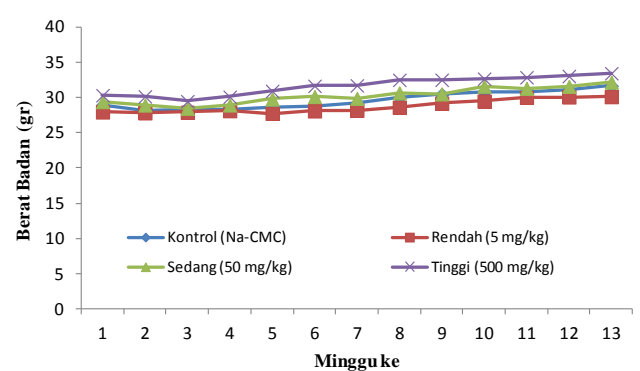

(b)

Gambar 1. Bobot badan Mencit Jantan (a) dan betina (b) Harian (rata-rata mingguan) pada Pemberian Dosis Fly ash 90 hari

Gambar 1 menjelaskan bahwa bobot badan rata-rata mingguan terjadi peningkatan dari awal sampai minggu 13 untuk mencit jantan (a) dan mencit betina (b), walaupun ada penurunan bobot badan mencit jantan (a) pada pemberian dosis rendah $5 \mathrm{mg} / \mathrm{kg}$ berat badan pada minggu ke 2 sampai 6 dan meningkat lagi sampai minggu ke 13 . Secara deskriptif bahwa pemberian dosis fly ash tidak menyebabkan penurunan bobot badan mencit yang nyata. Menurut Soemirat, 2003 bila terpapar suatu bahan mengandung logam berat maka akan menyebabkan keracunan atau toksik pada organ tertentu sehingga perkembangan berat badan akan terganggu

Kelompok satelit dilakukan untuk melihat sifat reversibel dari efek toksik, hasil pengamatan untuk kelompok satelit tersebut (Tabel 6).

Tabel 6. Bobot badan mencit (rata-rata mingguan) kelompok satelit

\begin{tabular}{|c|c|c|c|c|c|c|c|c|c|c|c|c|c|c|c|c|c|c|}
\hline \multirow{2}{*}{ Dosis } & \multicolumn{18}{|c|}{ Minggu Ke } \\
\hline & Awal & 1 & 2 & 3 & 4 & 5 & 6 & 7 & 8 & 9 & 10 & 11 & 12 & 13 & 14 & 15 & 16 & 17 \\
\hline \multicolumn{19}{|l|}{ Mencit Jantan } \\
\hline |Kontrol (Na-CMC) & 29,6 & 29,8 & 30 & 30,2 & 30,4 & 30,6 & 30,7 & 31,1 & 31,2 & 31,4 & 31,6 & 31,9 & 32,1 & 32,4 & 32,4 & 32,7 & 33,2 & 33,5 \\
\hline Tinggi (500 mg/kg) & 32,5 & 32,7 & 32,8 & 33,1 & 33,2 & 33,6 & 33,7 & 33,9 & 34,3 & 34,3 & 34,7 & 34,9 & 35 & 35,5 & 35,7 & 36 & 36,3 & 36,5 \\
\hline \multicolumn{19}{|l|}{ Mencit Betina } \\
\hline Kontrol (Na-CMC) & 31,3 & 31,4 & 31,4 & 31,4 & 31,7 & 31,8 & 31,8 & 32,2 & 32,2 & 32,6 & 32,6 & 33 & 33,2 & 33,3 & 33,5 & 33,7 & 34 & 34,1 \\
\hline Tinggi $(500$ mg/kg) & 29,8 & 30 & 29,9 & 30 & 30,2 & 30,3 & 30,2 & 30,6 & 30,6 & 30,9 & 31 & 31 & 31,3 & 31,4 & 31,6 & 31,6 & 32,2 & 32,2 \\
\hline
\end{tabular}

Tabel 6 menjelaskan bahwa bobot badan rata-rata mencit jantan dan betina ada kenaikan dari awal sampai minggu ke 17 walaupun minggu ke 14 sampai 17 dosis telah dihentikan. Hal ini menunjukkan bahwa pemberian dosis tidak mempengaruhi metabolisme makanan mencit sehingga perkembangan bobot badan ada peningkatan baik selama pemberian dosis maupun setelah pemberhentian dosis.

Bobot badan harian tersebut selanjutnya dilakukan perhitungan untuk mendapatkan nilai kenaikan bobot badan harian (ADG). Hasil ADG kelompok dosis dan satelit dapat dilihat pada (Tabel 7 dan 8).

Tabel 7. Purata Kenaikan Bobot Badan Mencit Jantan dan Betina Kelompok Dosis pada Pemberian Dosis Fly ash Berulang 90 Hari

\begin{tabular}{cccccc}
\hline \multirow{2}{*}{ Kelompok Dosis } & \multicolumn{4}{c}{ ADG \pm SD (gr/hari) } \\
\cline { 2 - 6 } & $\begin{array}{c}\text { Kontrol } \\
(\mathrm{Na}-\mathrm{CMC})\end{array}$ & $\begin{array}{c}\text { Rendah } \\
(5 \mathrm{mg} / \mathrm{kg})\end{array}$ & $\begin{array}{c}\text { Tengah } \\
(50 \mathrm{mg} / \mathrm{kg})\end{array}$ & $\begin{array}{c}\text { Tinggi } \\
(500 \mathrm{mg} / \mathrm{kg})\end{array}$ & $\mathrm{P}$ \\
\hline \multirow{2}{*}{ Jantan } & $0,03 \pm 0,02$ & $0,03 \pm 0,02$ & $0,02 \pm 0,01$ & $0,02 \pm 0,01$ & 0,82 \\
Betina & $0,03 \pm 0,01$ & $0,02 \pm 0,01$ & $0,03 \pm 0,01$ & $0,03 \pm 0,01$ & 0,05 \\
\hline
\end{tabular}

Hasil pengamatan pada Tabel 7 kenaikan bobot badan harian mencit jantan dosis rendah sama dengan kontrol $(0,03)$ dan dosis tengah dan tinggi berbeda dengan kontrol $(0,02)$. Mencit betina dosis rendah berbeda dengan kontrol, tengah dan tinggi mempunyai nilai sama dengan kontrol $(0,03)$. Hasil uji 
statistik Annova pada tabel di atas, tidak menunjukkan pengaruh yang nyata oleh pemberian dosis $f l y$ ash terhadap mencit jantan (P: 0,82) dan mencit betina (P: 0,05).

Perbedaan kenaikan bobot badan harian tersebut di atas tidak dipengaruhi oleh pemberian dosis $f l y$ ash, namun dipengaruhi oleh jenis kelamin dan asupan makanan. Hal ini disebabkan kandungan sifat toksik dari fly ash yang sangat rendah sehingga tidak mempengaruhi kenaikan bobot badan mencit. Menurut Vincent et al (2001), keadaan normal dan sehat bobot mencit bertambah seiring bertambah umur sampai batas tertentu. Pengamatan sifat reversibel dari pemberian dosis fly ash terhadap mencit kelompok satelit (Tabel 8).

Tabel 8. Purata Kenaikan Bobot Badan Mencit Jantan dan Betina Kelompok Satelit pada Pemberian Dosis Fly ash Berulang 118 Hari

\begin{tabular}{cccc}
\hline \multirow{3}{*}{ Kelompok satelit } & \multicolumn{3}{c}{ ADG \pm SD (gr/hari) } \\
\cline { 2 - 4 } & $\begin{array}{c}\text { Kontrol } \\
\text { (Na-CMC) }\end{array}$ & $\begin{array}{c}\text { Tinggi } \\
(500 \mathrm{mg} / \mathrm{kg})\end{array}$ & $\mathrm{P}$ \\
\hline Jantan & $0,03 \pm 0,02$ & $0,02 \pm 0,01$ & 0.667 \\
Betina & $0,03 \pm 0,01$ & $0,03 \pm 0,01$ & 0.354 \\
\hline
\end{tabular}

Hasil pengamatan Tabel 8 menunjukkan kenaikan bobot badan harian selama pemberian dosis dan setelah penghentian dosis mencit jantan ada penurunan dari kontrol $(0,03)$ ke dosis tinggi $(0,02)$ namun tidak berbeda nyata secara deskriptif sedangkan untuk mencit betina tidak ada perbedaan antara kontrol dan dosis tinggi. Hasil uji statistik Annova menunjukkan bahwa tidak ada pengaruh nyata antara kontrol dan dosis tinggi oleh pemberian dosis fly ash terhadap kenaikan bobot badan harian untuk kedua jenis kelamin kelompok satelit dimana mencit jantan nilai P: 0,667 dan betina P: 0,354.

Secara keseluruhan hasil penelitian menunjukkan bahwa pemberian dosis fly ash selama 90 hari dan dilanjutkan 28 hari masa pemulihan tidak berpengaruh nyata terhadap purata kenaikan bobot badan per hari (average daily gain) secara statistik, hal ini disebabkan karena karakteristik fly ash tidak teridentifikasi bersifat toksik dimana nilai TCLP dan $\mathrm{LD}_{50}$ dibawah baku mutu.

\section{Pengaruh pemberian dosis fly ash terhadap asupan makanan dan minuman mencit}

Hasil pengamatan asupan makanan harian mencit jantan dan betina kelompok dosis dapat lihat pada (Gambar 2).

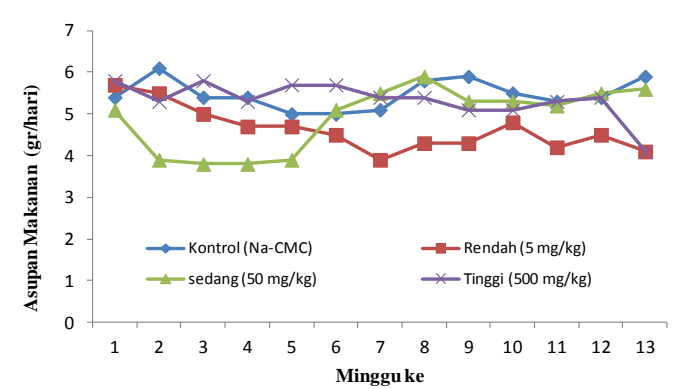

(a)

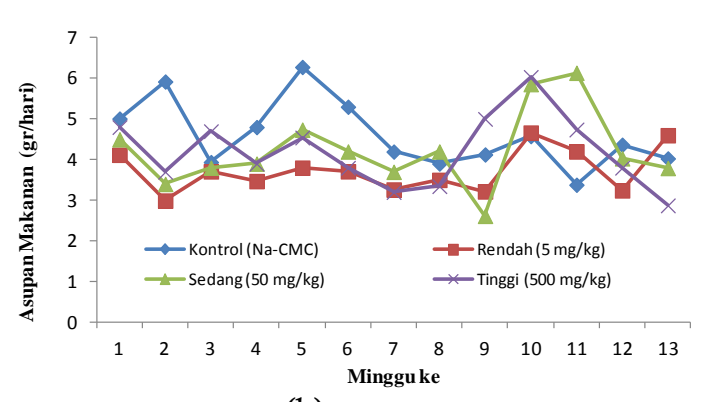

(b)

Gambar 2. Asupan Makanan Mencit Jantan (a) dan betina (b) Harian (rata-rata mingguan) pada Pemberian Dosis Fly ash 90 hari

Fluktuasi asupan makanan mencit jantan dan betina terjadi disebabkan oleh metode pemberian makanan masih perkelompok dan bobot mencit yang tidak seragam, sehingga sulit diidentifikasi per individu. Hasil pengamatan tersebut tidak ditemukan penurunan dan kenaikan asupan makanan yang naik atau turun drastis, hal ini menunjukkan bahwa pemberian dosis fly ash tidak terjadi gangguan metabolisme karena sifat toksik dari fly ash yang sangat rendah dan asupan makanan tersebut masih dalam standar asupan makanan tikus dewasa yaitu $15 \mathrm{gr} / 100$ gr berat badan/hari). (Malole dan Pramono, 1989) dan menurut Vincent et al (2001) tikus normal dan sehat tanpa diberi perlakuan asupan makanan fluktuatif. 
Fluktuasi asupan minuman mencit jantan dan betina kelompok dosis dapat dilihat pada (Gambar 3).

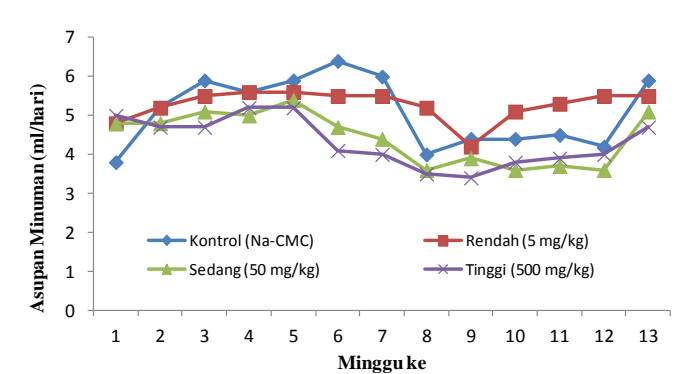

(a)

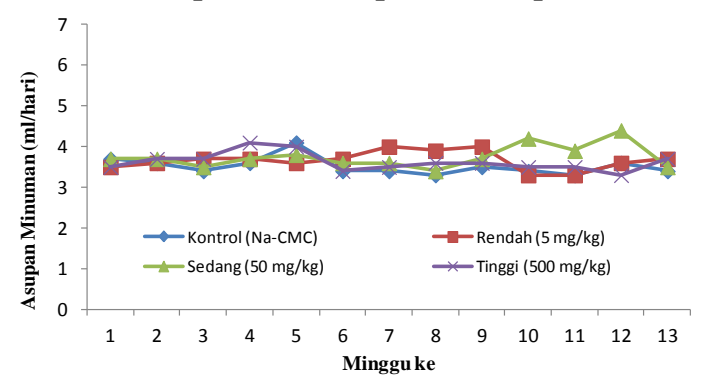

(b)

Gambar 3. Asupan Minuman Mencit Jantan (a) dan betina (b) Harian (rata-rata Mingguan) pada Pemberian Dosis Fly ash 90 hari

Gambar 3 menunjukkan asupan minuman mencit jantan (a) lebih tinggi dari mencit betina (b) dan mencit jantan (a) lebih fluktuatif dari mencit betina (b). Gambar tersebut menunjukkan bahwa secara deskriptif tidak ada perbedaan nyata pemberian dosis fly ash terhadap asupan minuman mencit jantan dan betina selama 13 minggu. Asupan minuman tidak ditemukan adanya penurunan yang drastis secara terpola. Hal ini disebabkan oleh kandungan fly ash yang mempunyai sifat toksik sangat rendah sehingga dosis fly ash tidak mempengaruhi asupan makanan dan minuman kedua jenis kelamin mencit. Asupan minuman tikus dewasa adalah $15 \mathrm{ml} / 100$ gr berat badan (Malole dan Pramono, 1989) dan fluktuasi asupan minuman terjadi pada tikus normal tanpa perlakuan (Vincent et al, 2001). Fluktuasi usapan makanan dan minuman mencit jantan dan betina kelompok satelit (Gambar 4).

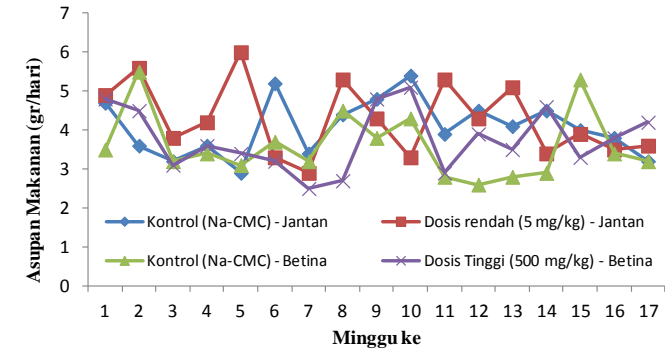

(a)

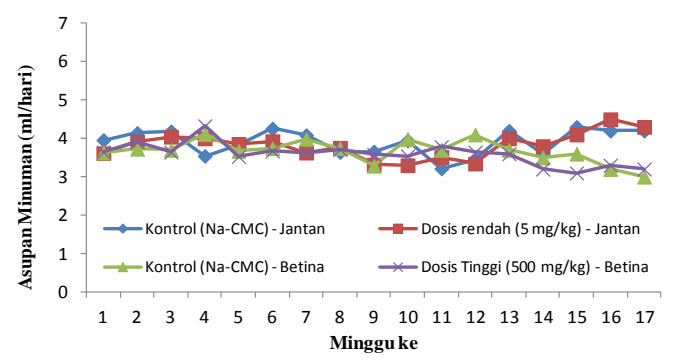

(b)

Gambar 4. Asupan Makanan (a) dan Minuman (b) Mencit Jantan dan Betina pada Kelompok Satelit (ratarata mingguan)

Selama pengamatan untuk kelompok satelit juga didapatkan bahwa asupan makanan dan minuman tidak jauh berbeda dengan kelompok dosis. Fluktuasi asupan makanan dan minuman tidak ditemukan penurunan atau peningkatan setelah penghentian dosis (minggu 14 sampai minggu 17).

\section{Pengaruh pemberian dosis fly ash terhadap hematologi mencit}

Hasil pemeriksaan hematologi yang dilakukan pada akhir uji sub kronis ini dapat dilihat pada (Tabel 9). Hasil ini merupakan purata hasil pemeriksaan hematologi setiap mencit (10 ekor) yang tabulasi dalam tabel. 
Tabel 9. Purata Hasil Pemeriksaan Hematologi Akhir Mencit Jantan pada Kelompok Dosis

\begin{tabular}{|c|c|c|c|c|c|c|}
\hline \multirow[b]{2}{*}{ Parameter } & \multicolumn{5}{|c|}{ Dosis } & \multirow[b]{2}{*}{ Refrensi } \\
\hline & $\begin{array}{c}\text { Kontrol } \\
(\mathrm{Na}-\mathrm{CMC})\end{array}$ & $\begin{array}{c}\text { Rendah } \\
(5 \mathrm{mg} / \mathrm{kg})\end{array}$ & $\begin{array}{c}\text { Tengah } \\
(50 \mathrm{mg} / \mathrm{kg})\end{array}$ & $\begin{array}{c}\text { Tinggi } \\
(500 \mathrm{mg} / \mathrm{kg})\end{array}$ & $\mathbf{P}$ & \\
\hline \multicolumn{7}{|l|}{ Mencit Jantan } \\
\hline$\overline{\mathrm{WBC}(\mathrm{x} 103 / \mu \mathrm{L})}$ & $7,53 \pm 3,04$ & $8,59 \pm 3,44$ & $7,17 \pm 2,58$ & $9,47 \pm 4,39$ & 0,405 & $2.69-18.02$ \\
\hline $\mathrm{RBC}(\mathrm{x} 106 / \mu \mathrm{L})$ & $6,89 \pm 1,58 \mathrm{a}$ & $8,03 \pm 0,80 \mathrm{ab}$ & $6,75 \pm 2,11 \mathrm{a}$ & $8,44 \pm 1,28 b$ & $0,042 *$ & $6,6-10,52$ \\
\hline $\mathrm{Hb}(\mathrm{g} / \mathrm{dL})$ & $12,0 \pm 3,7$ & $12,3 \pm 1,3$ & $10,0 \pm 3,2$ & $12,6 \pm 1,5$ & 0,107 & $11,0-17,3$ \\
\hline $\operatorname{HCT}(\%)$ & $51,1 \pm 4,0 b$ & $45,2 \pm 2,0 \mathrm{a}$ & $44,5 \pm 1,4 \mathrm{a}$ & $46,4 \pm 3,3 a$ & $0,0014 *$ & $33,1-51,1$ \\
\hline MCV (fl) & $52,3 \pm 3,8$ & $52,4 \pm 2,0$ & $52,1 \pm 3,7$ & $52,8 \pm 2,2$ & 0,96 & $41,1-52,8$ \\
\hline $\mathrm{MCH}(\mathrm{pg})$ & $15,2 \pm 1,3$ & $15,2 \pm 0,6$ & $14,7 \pm 1,2$ & $15,0 \pm 1,0$ & 0,89 & $14,1-17,8$ \\
\hline $\mathrm{MCHC}$ g/dL) & $29,0 \pm 0,7$ & $28,9 \pm 1,0$ & $28,12 \pm 0,9$ & $28,47 \pm 1,0$ & 0,119 & $32,2-37,2$ \\
\hline PLT $(x 104 / \mu L)$ & $119,2 \pm 32$ & $132,0 \pm 47,2$ & $128,2 \pm 30,3$ & $137,0 \pm 30,0$ & 0,724 & $73,0-180,8$ \\
\hline Lymph $(x 103 / \mu \mathrm{L})$ & $76,94 \pm 21,13$ & $64,36 \pm 17,30$ & $81,21 \pm 11,16$ & $69,67 \pm 14,93$ & 0,123 & - \\
\hline Lymp (x1000/ml) & $4,95 \pm 1,98$ & $5,49 \pm 2,0$ & $7,10 \pm 2,13$ & $6,27 \pm 2,78$ & 0,175 & - \\
\hline Neutr $(x 103 / \mu L)$ & $23,06 \pm 21,13$ & $35,64 \pm 17,30$ & $18,74 \pm 11,04$ & $30,33 \pm 14,93$ & 0,121 & - \\
\hline \multicolumn{7}{|l|}{ Mencit Betina } \\
\hline $\mathrm{WBC}(\mathrm{x} 103 / \mu \mathrm{L})$ & $2,9 \pm 1,2 \mathrm{a}$ & $3,3 \pm 0,8 \mathrm{a}$ & $4,92 \pm 2,2 b$ & $4,85 \pm 1,6 b$ & $0,007 *$ & $4,22-21,31$ \\
\hline $\mathrm{RBC}(\mathrm{x} 106 / \mu \mathrm{L})$ & $9,5 \pm 0,48$ & $9,38 \pm 0,35$ & $9,30 \pm 1,09$ & $9,68 \pm 0,48$ & 0,608 & $7,31-11,19$ \\
\hline $\mathrm{Hb}(\mathrm{g} / \mathrm{dL})$ & $14,3 \pm 0,6$ & $13,7 \pm 0,7$ & $13,9 \pm 1,4$ & $14,4 \pm 0,8$ & 0,304 & $13.1-17, .9$ \\
\hline $\operatorname{HCT}(\%)$ & $48,9 \pm 2,4$ & $47,7 \pm 2,4$ & $49,2 \pm 3,4$ & $50,0 \pm 2,7$ & 0,349 & $38,7-48,9$ \\
\hline $\operatorname{MCV}(\mathrm{fl})$ & $51,4 \pm 1,0$ & $50,9 \pm 1,3$ & $51,9 \pm 1,4$ & $51,7 \pm 0,8$ & 0,218 & $41,3-50,9$ \\
\hline $\mathrm{MCH}(\mathrm{pg})$ & $15,1 \pm 0,3$ & $14,6 \pm 0,6$ & $15,0 \pm 0,7$ & $15,1 \pm 1,0$ & 0,317 & $14,9-18,0$ \\
\hline $\mathrm{MCHC}$ g/dL) & $29,3 \pm 0,6$ & $28,7 \pm 0,7$ & $28,8 \pm 0,7$ & $28,8 \pm 0,718$ & 0,107 & $33,3-38,5$ \\
\hline PLT (x104/ $\mu \mathrm{L})$ & $114,7 \pm 16,8$ & $100,4 \pm 9,5$ & $119,4 \pm 16,8$ & $109,2 \pm 22,1$ & 0,091 & $40,2-152,7$ \\
\hline Lymph $(x 103 / \mu \mathrm{L})$ & $82,86 \pm 6,895$ & $84,01 \pm 3,872$ & $83,79 \pm 12,69$ & $80,17 \pm 7,745$ & 0,0727 & - \\
\hline Lymp (x1000/ml) & $2,81 \pm 1,52$ & $2,78 \pm 7,10$ & $4,21 \pm 2,25$ & $3,95 \pm 1,54$ & 0,106 & - \\
\hline Neutr $(x 103 / \mu L)$ & $17,14 \pm 6,89$ & $15,99 \pm 3,87$ & $16,21 \pm 12,69$ & $19,83 \pm 7,75$ & 0,727 & - \\
\hline
\end{tabular}

Ket: * nilai $\mathrm{P}<0,05$ dan nilai a,b dan c nilai uji lanjut

Hasil pengamatan Tabel 9 menunjukkan hampir semua parameter hematologi masih dalam batas kisaran referensi kecuali parameter MCV kedua jenis kelamin kelompok dosis termasuk kontrol yang di atas batas referensi. MCV untuk dosis kontrol mencit jantan 52,3 fl dari maksimum referensi $51,1 \mathrm{fl}$ dan mencit jantan $51,4 \mathrm{fl}$ dari $50.9 \mathrm{fl}$. Secara deskriptif tidak ada perbedaan nyata nilai hematologi pemberian dosis terhadap kontrol. Berdasarkan hasil uji statistik Annova untuk parameter tersebut bahwa pemberian dosis fly ash pada mencit jantan umumnya tidak berpengaruh nyata terhadap parameter hematologi dan hanya berpengaruh nyata terhadap parameter jumlah $\mathrm{RBC}$ (P:0,042) dan berpengaruh sangat nyata terhadap HCT (P:0,0014) namun kedua parameter tersebut masih dalam kisaran referensi. Hasil uji statistik lanjut Ducan untuk dua parameter itu menunjukan bahwa perbedaan terjdi pada kelompok dosis tinggi terhadap kelompok kontrol saja untuk parameter RBC dan parameter HTC perbedaan terjadi untuk kelompok dosis rendah, tengah dan tinggi terhadap kelompok kontrol namun untuk masing kelompok dosis tidak berbeda nyata.

Hasil uji statistik Annova terhadap mencit betina hanya berpengaruh nyata terhadap parameter WBC (P: 0,007). Analisis statistik lanjut (Ducan) terhadap parameter tersebut, perbedaan terjadi pada kelompok dosis tengah dan tinggi terhadap kontrol dan dosis rendah serta tidak ada perbedaan nyata untuk dosis tengah dan tinggi. Hasil pemeriksaan hematologi kelompok setelit untuk melihat sifat reversibel pemberian dosis tertera pada (Tabel 10).

Tabel 10. Purata Hasil Pemeriksaan Hematologi Akhir Mencit Jantan pada Kelompok Satelit

\begin{tabular}{lcccccc}
\hline \multirow{2}{*}{ Parameter } & \multicolumn{2}{c}{ Satelit Jantan } & \multicolumn{4}{c}{ Satelit Betina } \\
\cline { 2 - 7 } & $\begin{array}{c}\text { Kontrol } \\
(\mathrm{Na}-\mathrm{CMC})\end{array}$ & $\begin{array}{c}\text { Tinggi } \\
(500 \mathrm{mg} / \mathrm{kg})\end{array}$ & Refrensi & $\begin{array}{c}\text { Kontrol } \\
(\mathrm{Na}-\mathrm{CMC})\end{array}$ & $\begin{array}{c}\text { Tinggi } \\
(500 \mathrm{mg} / \mathrm{kg})\end{array}$ & Refrensi \\
\hline WBC & $8.96 \pm 3.4$ & $7.36 \pm 1.8$ & $6.6-10.52$ & $6.2 \pm 2.1$ & $7.02 \pm 5.6$ & $7.31-11.19$ \\
RBC & $9.05 \pm 1.01$ & $8.19 \pm 1.60$ & $2.69-18.02$ & $9.10 \pm 0.62$ & $9.11 \pm 2.07$ & $4.22-21.31$ \\
Hb (g/dL) & $13.2 \pm 1.5$ & $12.4 \pm 2.5$ & $11.0-17.3$ & $13.6 \pm 1.3$ & $13.2 \pm 3.0$ & $13.1-17.9$ \\
HCT (\%) & $47.5 \pm 3.4$ & $46.2 \pm 7.6$ & $33.1-51.1$ & $47.3 \pm 4.5$ & $45.4 \pm 11.0$ & $38.7-48.9$ \\
MCV (fl) & $50.6 \pm 1.2$ & $53.9 \pm 1.0$ & $41.1-52.8$ & $51.9 \pm 2.0$ & $49.6 \pm 2.2$ & $41.3-50.9$ \\
MCH (pg) & $14.5 \pm 0.3$ & $15.2 \pm 0.3$ & $14.1-17.8$ & $15.0 \pm 0.7$ & $14.4 \pm 0.5$ & $14.9-18.0$ \\
MCHC g/dL) & $28.78 \pm 0.6$ & $28.18 \pm 0.4$ & $32.2-37.2$ & $28.8 \pm 0.4$ & $29.12 \pm 0.8$ & $33.3-38.5$ \\
PLT & $118.5 \pm 42.8$ & $131.3 \pm 20.0$ & $73.0-180.8$ & $95.6 \pm 22.4$ & $82.8 \pm 30.7$ & $40.2-152.7$ \\
Lymph & $5.4 \pm 2.3$ & $6.2 \pm 2.1$ & - & $5.08 \pm 1.48$ & $3.4 \pm 4.4$ & - \\
Neutr & $3.6 \pm 3.2$ & $2.1 \pm 0.9$ & - & $1.48 \pm 0.3$ & $3.62 \pm 6.0$ & - \\
\hline
\end{tabular}


Hasil Tabel 10 menjelaskan semua parameter hematogi masih dalam batas referensi kecuali parameter MCV mencit jantan dosis tinggi dan MCV mencit betina dosis kontrol yang melewati batas tertinggi referensi. Hasil tersebut secara keseluruhan tidak ada perbedaan nyata nilai hematologi dosis tinggi terhadap dosis kontrol sehingga penghentian pemberian dosis fly ash tidak berpengaruh secara klinis terhadap sifat reversibilitas parameter hematologi mencit jantan dan betina. Hasil Pengamatan secara keseluruhan dapat disimpulkan bahwa pemberian dosis fly ash terhadap hewan uji mencit tidak berpengaruh terhadap hematologi secara permanen, hal ini disebabkan karena sifat toksikologi fly ash yang rendah berdasarkan hasil uji TCLP dan $\mathrm{LD}_{50}$.

\section{Pengaruh pemberian dosis fly ash terhadap kimia klinik darah mencit}

Hasil pemeriksaan kimia darah meliputi glukosa, protein total, albumin, kolesterol, ALT (Alanine Aminotransferase), AST (Aspartan Aminotransferase), bilirubin total, dan kreatinin serum pada penelitian dapat dilihat pada (Tabel 11).

Tabel 11. Purata Hasil Pemeriksaan Akhir Kimia Klinik Mencit pada Kelompok Dosis

\begin{tabular}{|c|c|c|c|c|c|c|}
\hline \multirow[b]{2}{*}{ Parameter } & \multicolumn{5}{|c|}{ Dosis } & \multirow[b]{2}{*}{ Refrensi } \\
\hline & $\begin{array}{c}\text { Kontrol } \\
\text { (Na-CMC) }\end{array}$ & $\begin{array}{c}\text { Rendah } \\
(5 \mathrm{mg} / \mathrm{kg})\end{array}$ & $\begin{array}{c}\text { Tengah } \\
(50 \mathrm{mg} / \mathrm{kg})\end{array}$ & $\begin{array}{c}\text { Tinggi } \\
(500 \mathrm{mg} / \mathrm{kg})\end{array}$ & $\mathbf{P}$ & \\
\hline \multicolumn{7}{|l|}{ Mencit Jantan } \\
\hline Glukosa (mg/dL) & $165,23 \pm 21,47$ & $160,02 \pm 29,53$ & $152,01 \pm 37,11$ & $148,03 \pm 20,62$ & 0,52 & $68-271$ \\
\hline Protein (gr/dL) & $5,61 \pm 0,73$ & $5,41 \pm 0,49$ & $5,52 \pm 0,68$ & $5,66 \pm 0,38$ & 0,778 & $4.3-6.3$ \\
\hline Albumi (gr/dL) & $3,14 \pm 0,46$ & $2,98 \pm 0,3$ & $3,05 \pm 0,23$ & $3,08 \pm 0,19$ & 0,715 & $2.1-3.9$ \\
\hline Kolesterol (mg/dL) & $95,91 \pm 45,13$ & $95,74 \pm 30,18$ & $89,32 \pm 25,27$ & $119,78 \pm 26,75$ & 0,19 & $81-190$ \\
\hline $\operatorname{ALT}(\mathrm{U} / \mathrm{l})$ & $56,25 \pm 20,07$ & $60,00 \pm 18,15$ & $53,64 \pm 21,58$ & $45,16 \pm 13,30$ & 0,295 & $23-155$ \\
\hline AST (U/L) & $87,53 \pm 36,00$ & $84,35 \pm 40,12$ & $88,26 \pm 21,14$ & $72,08 \pm 27,61$ & 0,652 & $35-268$ \\
\hline Billirubin (mg/dL) & $0,28 \pm 0,14$ & $0,22 \pm 0,15$ & $0,36 \pm 0,11$ & $0,38 \pm 0,15$ & 0,05 & $0.15-0.40$ \\
\hline Kreatinin (gr/dL) & $0,25 \pm 0,07 \mathrm{a}$ & $0,20 \pm 0,066 \mathrm{a}$ & $0,46 \pm 0,24 b$ & $0,47 \pm 0,17 b$ & $0,002 *$ & $0.1-0.8$ \\
\hline \multicolumn{7}{|l|}{ Mencit Betina } \\
\hline Glukosa (mg/dL) & $161,97 \pm 25,52$ & $159,32 \pm 29,04$ & $147,33 \pm 18,34$ & $157,51 \pm 21,22$ & 0,546 & $83-215$ \\
\hline Protein (gr/dL) & $5,44 \pm 0,34$ & $5,2 \pm 0,22$ & $5,33 \pm 0,48$ & $5,65 \pm 0,39$ & 0,064 & $4.8-5.9$ \\
\hline Albumi (gr/dL) & $3,27 \pm 0,23$ & $3,14 \pm 0,11$ & $3,09 \pm 0,23$ & $3,29 \pm 0,19$ & 0,076 & $2.9-4.3$ \\
\hline Kolesterol (mg/dL) & $81,61 \pm 14,31$ & $80,88 \pm 14,24$ & $97,16 \pm 27,94$ & $104,19 \pm 27,17$ & 0,055 & $56-153$ \\
\hline ALT (U/L) & $42,94 \pm 13,64$ & $44,81 \pm 20,28$ & $46,09 \pm 22,42$ & $55,67 \pm 22,8$ & 0,54 & $20-160$ \\
\hline AST (U/L) & $63,57 \pm 20,61 \mathrm{a}$ & $52,87 \pm 28,33 \mathrm{ab}$ & $91,87 \pm 53,89 \mathrm{~b}$ & $99,98 \pm 46,15 \mathrm{~b}$ & $0.034 *$ & $46-112$ \\
\hline Billirubin (mg/dL) & $0,07 \pm 0,067 \mathrm{a}$ & $0,06 \pm 0,069 \mathrm{a}$ & $0,39 \pm 0,25 \mathrm{~b}$ & $0,34 \pm 0,096 \mathrm{~b}$ & $0,00002 *$ & $0.10-0.9$ \\
\hline Kreatinin (gr/dL) & $0,24 \pm 0,05 \mathrm{a}$ & $0,19 \pm 0,09 \mathrm{a}$ & $0,56 \pm 0,12 \mathrm{~b}$ & $0,58 \pm 0,06 \mathrm{~b}$ & $0,004 *$ & $0.1-0.6$ \\
\hline
\end{tabular}

Ket: * nilai $\mathrm{P}<0,05$ dan nilai $\mathrm{a}, \mathrm{b}$ dan $\mathrm{c}$ nilai uji lanjut

Tabel 11 merupakan hasil analisa parameter kimia klinik darah yang mejelaskan kondisi metabolisme didalam tubuh mencit. Hasil di atas menunjukkan bahwa semua parameter kimia darah masih dalam referensi dan tidak ada perbedaan yang nyata antara kempok dosis dengan kontrol. Hasil uji statistik Annova untuk mencit jantan menunjukkan bahwa pemberian dosis fly ash berpengaruh nyata pada kreatinin (P:0,002) dan uji statistik Annova untuk mencit betina menunjukkan bahwa pemberian dosis fly ash mempunyai pengaruh nyata terhadap parameter AST (P: 0,034), Bilirubin $(\mathrm{P}: 0,002)$ dan Kreatinin (P: 0,004). Hal ini dapat disimpulkan bahwa pemberian dosis berpengaruh nyata terhadap fungsi ginjal mencit jantan dan fungsi hati dan ginjal mencit betina, namun pengaruh tersebut hanya bersifat sementara karena setelah pemberhentian dosis pada kelompok satelit parameter tersebut normal kembali. dimana bilirubinnya $0,4 \mathrm{gr} / \mathrm{dL}$ pada kelompok kontrol dan $0,4 \mathrm{gr} / \mathrm{dL}$ pada kelompok dosis tinggi dan kreatinin $0,2 \mathrm{gr} / \mathrm{dL}$ pada kelompok kontrol dan $0,2 \mathrm{gr} / \mathrm{dL}$ pada kelompok dosis tinggi. Hasil analisis kimia darah kelompok satelit dapat dilihat pada (Tabel 12).

Tabel 12. Purata Hasil Pemeriksaan Akhir Kimia Klinik Mencit pada Kelompok Satelit

\begin{tabular}{ccccccc}
\hline \multirow{2}{*}{ Parameter } & \multicolumn{3}{c}{ Satelit Jantan } & \multicolumn{3}{c}{ Satelit Betina } \\
\cline { 2 - 7 } & $\begin{array}{c}\text { Kontrol } \\
(\mathrm{Na}-\mathrm{CMC})\end{array}$ & $\begin{array}{c}\text { Tinggi } \\
(500 \mathrm{mg} / \mathrm{kg})\end{array}$ & Refrensi & $\begin{array}{c}\text { Kontrol } \\
(\mathrm{Na}-\mathrm{CMC})\end{array}$ & $\begin{array}{c}\text { Tinggi } \\
(500 \mathrm{mg} / \mathrm{kg})\end{array}$ & Refrensi \\
\hline Glukosa (mg/dL) & $156.8 \pm 48.9$ & $164.7 \pm 33.0$ & $68-271$ & $167.4 \pm 44.9$ & $160.6 \pm 36.4$ & $83-215$ \\
Protein (g/dL) & $5.7 \pm 0.6$ & $4.9 \pm 0.4$ & $4.3-6.3$ & $5.4 \pm 0.6$ & $5.0 \pm 0.5$ & $4.8-5.9$ \\
Albumin (g/dL) & $3.3 \pm 0.5$ & $3.0 \pm 0.2$ & $2.1-3.9$ & $3.0 \pm 0.4$ & $3.1 \pm 0.3$ & $2.9-4.3$ \\
Kolesterol & $115.9 \pm 43.8$ & $109.3 \pm 22.0$ & $81-190$ & $79.5 \pm 12.3$ & $64.1 \pm 16.5$ & $56-153$ \\
ALT (U/L) & $58.7 \pm 11.3$ & $56.1 \pm 20.4$ & $23-155$ & $33.8 \pm 11.2$ & $38.5 \pm 16.7$ & $20-160$ \\
AST (U/L) & $90.7 \pm 41.0$ & $63.6 \pm 17.1$ & $35-268$ & $82.6 \pm 24.2$ & $104.7 \pm 40.3$ & $46-112$ \\
Bilirubin (mg/dL) & $0.4 \pm 0.2$ & $0.3 \pm 0.3$ & $0.15-0.40$ & $0.4 \pm 0.2$ & $0.4 \pm 0.5$ & $0.10-0.9$ \\
Kreatinin (mg/dL) & $0.2 \pm 0.1$ & $0.2 \pm 0.2$ & $0.1-0.8$ & $0.2 \pm 0.0$ & $0.2 \pm 0.2$ & $0.1-0.6$ \\
\hline
\end{tabular}


Tabel 12 menunjukkan bahwa semua parameter kimia darah kelompok satelit masih dalam batas referensi. Mencit jantan pada umumnya terjadi penurunan kadar kimia darah, namun untuk parameter glukosa terjadi peningkatan. Mencit betina peningkatan terjadi pada parameter ALT dan albumin, sehingga secara umum dapat disimpulkan bahwa pemberian dosis fly ash terhadap mencit tidak berpengaruh nyata terhadap analisis biokimia klinik dan fungsi hati, ginjal dan linpa karena hasil analisis kimia klinik masih dalam referensi. Hal ini disebabkan oleh kandungan kadar toksik dalam fly ash yang sangat rendah.

\section{KESIMPULAN}

Uji karakteristik limbah B3 fly ash PT RAPP memenuhi baku mutu PP No. 101 tahun 2014. Hasil uji Sub kronis menunjukkan pemberian dosis berulang dengan tingkat dosis $0 \mathrm{mg} / \mathrm{kg}$ berat badan, $5 \mathrm{mg} / \mathrm{kg}$ berat badan, $50 \mathrm{mg} / \mathrm{kg}$ berat badan dan $500 \mathrm{mg} / \mathrm{kg}$ berat badan tidak berpengaruh terhadap sistem susunan saraf pusat dan somatomotor, saraf otonom, pernafasan, kardiovaskular, saluran cerna, genitourinari, membran mukosa dan mata, perubahan bobot badan, asupan makanan, dan minuman, secara umum tidak mempengaruhi parameter hematologi dan kimia klinik darah, Berdasarkan hasil uji sub kronis keseluruhan dapat diidentifikasi bahwa No-Observed-Adverse-Effect Level (NOAEL) tidak ditemukan atau ambang batas efek toksik lebih besar dari dosis tertinggi $500 \mathrm{mg} / \mathrm{kg} \mathrm{BB}$. Berdasarkan hasil dipenelitian ini disarankan agar PT RAPP berkoordinasi dengan KLHK untuk melakukan studi lebih lanjut untuk pengecualian pengelolaan fly ash sebagai limbah B3.

\section{UCAPAN TERIMAKASIH}

Ucapan terima kasih penulis sampaikan kepada semua pihak yang telah banyak membantu terlaksananya penelitian ini.

\section{DAFTAR PUSTAKA}

Anonim., 2006. Pengkajian Pemanfaatan Boiler ash untuk Land Aplication di Areal Lahan Hutan Tanaman Industri (HTI) PT RAPP, Kerjasama antara PT RAPP dengan Balai Besar Pulp dan Kertas (BPPK)

Juli Soemirat., 2003, Uji toksisitas kualitatif, dalam, Toksikologi lingkungan. Gadjah Mada University Press, Yogyakarta

Malole, M. B. B., dan C. S. U. Pramono, 1989,. Penggunaan Hewan-hewan Percobaan di Laboratorium. Institut Pertanian Bogor, Bogor.

Peraturan Pemerintah No. 101 Tahun 2014 tentang Pengelolaan Limbah Berbahaya dan Beracun, Sekretaris Negara. Jakarta

Purwati, S, Soetopo R dan Yusup S .,2007, Potensi Penggunaan Abu Boiler Industri Pulp dan Kertas Sebagai Bahan Penkondisi Lahan Gambut Pada Areal Hutan Tanaman Industri, dalam Jurnal..Berita Selulosa Vol. (42) 1. Bandung.

US EPA., 2015, Federal Register, Hazardous and Solid Waste Management System of Coal Conbustion Residuals From Electric Utilities Final Rule, NARA, Vol 80, No. 74,USA.

Vincent V.R, Mark W and Micheal D.M., 2001. Acute and Sub Kronic Mammilian Toxicity of Naphthenic Acid from Oil Tailling. Toxicological Science 66,37-355-2002. 